\title{
Business improvement districts: The impact of their introduction on retailers and leisure operators
}

Received: 7 May 2003

\section{Stephen Ashworth}

is a partner in the planning and public law team at DWS, and the chair of the Circle Initiative. Supported by the London Development Agency, the Circle Initiative comprises five partnerships working to achieve BID status in Holborn, Waterloo, Bankside, Paddington and Piccadilly Circus. Stephen spent 12 months in the USA researching mechanisms for managing the public realm such as BIDs and, together with the BPF, ATCM, LGA and others, has been drafting amendments to the emerging BIDs legislation recently proposed in the House of Lords.

\section{Abstract}

Business improvement districts (BIDs) are high on the political agenda in the UK. Legislation is going through Parliament that will give them a statutory form by April 2004. With the welcome attention being given by government, the Commission for Architecture and the Built Environment and the property industry to improving the public realm, BIDs seem to be an idea whose time has come. This paper outlines the history of BIDs, explains how they are likely to operate in the UK, looks at the lessons that are being learnt from the ongoing BID pilots and looks at the implications for retailers and leisure operators.

\section{Keywords:}

additionality, clean and safe, partnerships, property owner involvement, Circle Initiative, urban space management

\section{HISTORY}

At their simplest BIDs are organisations entitled to levy an additional property tax within a specified area for providing a defined range of services or carrying out specific works. The concept of BIDs is not new. Ironically, to a large extent they were born in England. In 1250 local residents near Romney Marsh were assessed to pay for repairs to sea walls. The assessments were made in proportion to the acreage of the land owned and benefited by the sea walls. Sewers were funded this way from as early as 1427 ,

Stephen Ashworth Scarborough Pier was paid for in 1545 and various 'castells and were specially assessed as early as 1576 .

Although it is too wide a generalisation, at the time voters tended to be property owners, so that those who were voting tended to be 


\section{Supplementarity}

Who pays? those paying the additional taxes. In the UK, as the tax base (and voting base) moved away from property this type of assessment system died. Although there have been attempts since the Second World War to explore betterment levies and other property-based taxes, these have not had any real political or public support and have never been followed through.

\section{THE AMERICAN MODEL}

Accordingly, BIDs emerged from this historical background largely in America. The approach which is now proposed to be introduced in the UK relies, to a large extent, on American experience over the past 20 years or so. In the main, US BIDs have been business led, with businesses opting (usually by a referendum) to impose an additional property tax within a self-defined area. They have focused on providing supplementary services to those normally provided by local government. They have, for example, concentrated on advertising the promotion of the area, improving signage, maintaining cleanliness and providing visible security measures. The bulk of attention has been paid to 'clean and safe' activities. The overwhelming desire has been to make sure that streets are properly cleansed, and that the type of low-level crime that was driving people away from American downtowns ceased.

Obviously, there have been exceptions to this. In New York, a BID based around Bryant Park made significant environmental improvements, at a considerable capital cost, to a local park. Capital finance has been raised by a number of New York BIDs, with the future tax assessments being used to finance bonds. In Chicago significant sums have been raised, on a more traditional special assessment basis, to fund feasibility studies and land purchases in anticipation of a new light rapid-transit system. In other areas, for example in Wisconsin, BIDs have been used to make significant contributions towards conference facilities and other civic amenities.

\section{Allocation of BID costs}

There are a significant number of ways of allocating out the total budget of a bill to property owners. In most cases, non-commercial premises are excluded, or only pay a nominal amount. Residents, for example, are often only charged a nominal US\$1 fee. Although residential properties are usually ignored, a number of purely residential-based 'BIDs' have been promoted. Chicago, for example, publishes a guide directly focused on residential schemes. Churches and government offices, which are tax-exempt in the USA, are not normally required to contribute.

The apportionment of any budget is also subject to significant variations. In most cases the process is a simple allocation of the costs according to the value of the commercial premises in the area. Occasionally it is dealt with on a rather more sophisticated basis with the equivalent of zone A rentals being used, or with discounts 
Start-up costs

\section{Competing services}

given to those at the top of towers who do not quite so directly benefit from BID activities. In predominantly retail-based BIDs, costs have been allocated according to frontage rather than value. Occasionally costs have been allocated according to total floorspace. More unusually, one US BID (which did not last long) attempted to allocate costs according to footfall along the retail frontage, so that those who were in off-pitch areas did not pay as much as those who were in the prime pitch, where much more use was made of the additional cleaning and security services. In practice, most of the American legislative systems provide a great deal of flexibility.

\section{Setting up BIDs}

The process by which BIDs emerge is also different from location to location. There are, almost always, elections or referenda. In New York there is a process of requiring prospective BIDs to produce business plans and then to persuade a majority of landowners to participate. In practice, the New York City Department of Business Services vets all potential schemes, and only allows those that are likely to succeed to move forward to an election. As a consequence, the levels of approval always appear to be between 75 per cent and 90 per cent.

In many areas the elections require that at least 51 per cent of the assessed value of all property as well as 51 per cent of all the owners (by number) vote in favour of a BID. Elsewhere the elective thresholds are set higher, and procedural requirements are more rigorous. In some locations the administrative costs of constituting the BID are not claimable, which means that there must be real and committed sponsors, with deep pockets, from the outset.

\section{Operation}

In operation, BIDs take many forms. The different types of organisation can start from a single person effectively dealing with matters alone. The Lincoln Road Retail Partnership in Miami operates with a minute staff, and was largely the initiative of a single person. BIDs in Madison in Wisconsin share staff. Others, such as the Grand Central Partnership in New York, have chief executives and a whole panoply of different advisers. Necessarily the staff and the organisation fit the purpose of the BID. Clearly, the nature of the management and the administration reflects the needs of local circumstances.

Any BID will need to procure services. This has been an area fraught with difficulties. There are often legislative controls on the BIDs contracting, or contracting above a certain financial level, with members. There are often 'public procurement' type controls on who can be employed. In New York concerns were raised at one stage about BIDs using labour being paid below acceptable city 


\section{Emerging legislation}

\section{Voting tests}

salary levels. There is also an irony in that the main provider of many of the services is the local government body itself. They have the facilities to clean, maintain etc without huge additional start-up costs. The contracts therefore specify increases in levels of service. This can be one of the most important elements of the role of the BID since it requires local government to define what it will do, as a minimum, so that the excess can be paid for separately. It benchmarks and underwrites core standards of service.

\section{HOW DOES ALL OF THIS TRANSLATE INTO THE UK EXPERIENCE?}

At the moment, legislation is progressing through Parliament that will allow BIDs to be set up from April 2004. The approach being adopted is relatively simple. A BID proposal can be brought forward by anyone interested in setting up a BID. The BID proposal will have to define the proposed BID area and the charge that is proposed. The charge will be paid by each rateable occupier, although there appears to be some flexibility in the legislation that will allow different classes of occupier to pay differing amounts. It is assumed that this will allow, for example, office occupiers in a shopping centre to be exempted from charges when the proposed BID is primarily involved in providing services direct to the retailers. In practice, any BID proposal will need to be supported by a relatively detailed business plan outlining the nature and type of services that it is proposed will be provided. It will have to have been drawn up in conjunction with those normally providing the service - primarily the local authority wearing its highways, cleaning and other related hats. Partnerships will also need to be developed with, for example, the police and, potentially, statutory undertakers to manage the area successfully.

A BID proposal has to be vetted by the local authority, which is responsible for organising and running an election. Mirroring the American approach, a BID will only come into effect if, after an election, over 51 per cent of those being asked to contribute, on a head-count basis, agree to pay. There is also a requirement that votes representing at least 50 per cent of the rateable value within the BID area vote in favour. These 'dual tests' are meant to offer protection to individual property owners. It should mean that small retailers, leisure operators and other occupiers cannot be railroaded into a BID simply because two or three of the larger property occupiers want one; similarly, a large occupier has a measure of protection against the smaller operators 'ganging up'. A local authority is not required to assist with BID election, but if they refuse to do so, there is a right of appeal to the Secretary of State. The Secretary of State can require a BID process to proceed. BIDs will only last five years at most. After that time there will need to be a further election. Only if a BID has persuaded contributors that it is worthwhile will it continue. 
There is one fundamental omission from the present legislation. As a matter of administrative ease, the government has chosen to graft a BID system on to the present rates system. Unfortunately, this means that there is no specific place within BIDs for property owners other than those who are rateable occupiers. It is anticipated that property owners will be able to contribute 'voluntarily' but they will not form part of the formal BID process. This situation is bizarre. Almost everyone with experience of present town-centre management schemes, those who have researched BIDs overseas, those involved in pilot BIDs in the UK and major property owners have all been lobbying for property owners to be included. At first, it was indicated that it would be 'too complex' to include property owners. A lobbying group comprising the British Property Federation, the British Retail Consortium, the Association of Town Centre Management, the Prudential, Land Securities, the Circle Initiative, the New West End Company and numerous other bodies prepared draft legislation which could address this concern. It was relatively easy. The Circle Initiative sponsored a 'real-life' report that demonstrated how it could work in practical terms around Piccadilly Circus, where a pilot BID is already operating.

The government then changed its argument. The issue was said to be that the government did not wish to introduce a 'new tax'. Given the list of people who are arguing that they should be taxed (if indeed it is a tax), this seems strange. There are relatively few cases where such a coalition of the property industry is inviting a new tax. At the committee stage in the House of Commons, both Conservative and Liberal members promoted changes that would allow property owners to be charged. There is no real political opposition. It is difficult to see any real political risk.

This is not a sterile argument. Necessarily, rateable occupiers concentrate on the short term. Tomorrow's pedestrian traffic and profit is more important for a store manager than how the area as a whole will be operating in five years' time. While the major retailers and leisure operators can afford to take a longer-term view, a lot of the industry necessarily operates more on a hand-tomouth basis. There is a real danger that they will choose not to support a BID, and BIDs will not pass the initial election process. Even more worryingly, there is a real risk that they will see that they are paying for additional services and improvements to the public realm that will be benefiting the landlord. If the area improves, the rents are likely to increase (along with the capital values) and the retailer will simply be asked to pay more, in part at least as a consequence of having paid for improvements in the area. There is an obvious inequity in this. There is a need for the property, leisure and retail industries to combine to lobby government on this. While the proposed BIDs legislation is welcome, it would be a tragedy if the opportunity to bring together all those with interests was not taken. 
Pilot projects

\section{Circle Initiative}

\section{Emerging lessons}

\section{EXPERIENCE OF BIDS IN THE UK}

There are a number of pilot BIDs in the UK, the best developed of which are in London and in Coventry. The first prototype BID was, probably, the South Bank Employers Group. Most of the major employers on the south bank of the River Thames between Blackfriars Bridge and Westminster Bridge have cooperated for over a decade to try to improve the area. It has had a dramatic effect, with major improvements to the highway and road infrastructure and to the public realm, and has been one of the reasons for a complete change in the character of the area. In the West End, the New West End Company is promoting changes to Oxford Street, Bond Street and Regent Street in the context of an ongoing master-plan process.

The first formal BID pilots are those led by the Circle Initiative. The Circle Initiative was developed by the Central London Partnership and sponsored by the London Development Agency. It coordinates five separate model BIDs in:

- Piccadilly Circus

- Holborn

- Paddington

- Waterloo

- Bankside.

All of the BIDs are different. The Waterloo BID covers a small street, Lower Marsh, behind Waterloo in which independent retailers and a market operate. Holborn is largely office-occupier based, while Paddington is focused on Praed Street, but with very close connections to the large-scale development presently taking place at Paddington.

After two-and-a-half years there are a number of emerging lessons.

- It takes significant time, money and real commitment to bring forward a BID. It has taken two years to draw together the necessary coalitions to promote each of the BIDs and to agree on the organisational approach required.

- It has a significant cost. There is the obvious cost of everybody's time. There is also a need to promote projects, from an early stage, which provide an example of the benefits that are likely to be received.

- There is a very real need for local authority engagement. A large part of what the pilot BIDs have been achieving is to focus and coordinate local authority efforts in an area, to make sure that the services are tailored towards the real needs of the environment.

- People are key: having the right people allows a BID to succeed. The wrong people can, effectively, kill it.

- There is a need for property owners' involvement in most cases. 
They have provided a significant part of the matching finance required.

All of these lessons will need to be fed into the setting up of new BIDs once the legislation is in place.

\section{IMPLICATIONS}

BIDs will happen. The precise form of them remains uncertain but by April 2004 there will be a mechanism for a business-led partnership to promote a BIDs scheme. Subject to satisfying the electoral criteria, well-funded BIDs will be able to make a real contribution towards the improvement of their areas. What are they likely to do? The main areas for the first BIDs will be to concentrate on the 'clean and safe' issues in the same way as the American BIDs initially focused on these concerns. In most cases, local authorities already provide the services that are needed, and BIDs will be focused mainly on making sure that they are provided better and in a way which is more relevant to the area. There may be occasions, as has happened in Piccadilly, where additional services are procured, supplementing the local authority services. Retailers and leisure operators should see cleaner, safer streets and open spaces as a consequence. The public realm should end up being better managed.

There is likely to be an emphasis on making areas more legible. In part, this will be about 'branding'. BIDs will necessarily have to define their own area, and making sure that it has a common identity will be important. This will be achieved partly by signage, partly by physical improvement projects and partly by services such as rangers, which will all 'badge' the area. In Holborn many are already conscious of the existence of the Holborn Business Partnership because there are red-coated rangers around, emblazoned with the HBP logo. Effectively, BIDs will promote areas and encourage higher visitor and customer numbers.

Retail and leisure operators will be making a large part of the contribution to most BIDs. They will be able to set the goals, and help to define the way in which the areas in which they operate change. For the first time in a long while, there will be a real and well-funded link through to local authorities that can be used to influence the services which they provide. To some extent, operators will be able to manage parts of the public realm in a similar way to the way in which they manage their own units. The trading space will be extended - with the common parts far better managed than at present.

Obviously, this is not pain-free gain. There will be an additional cost for business. In a perfect market, rents will be adjusted to take account of it, although that can only ever happen with a time lag and doubtless will never be transparent.

Faith and trust

A vote for a BID therefore will, to some extent, be a matter of faith. Retailers and leisure operators will have to be confident that 
a BID will actually deliver a better environment, better services and a better public realm, resulting in additional trade. In practice, the second election will be the key test. The successful BID will be one which, like a prime minister, needs to be re-elected. Like a prime minister, a BID may often succeed primarily because there is no better alternative. That is a slightly sad comment on the present system of urban space management. 